\title{
ANALISIS YAJNA SEBAGAI DASAR PENGEMBANGAN MUTU KARAKTER PESERTA DIDIK DI SEKOLAH MENENGAH PERTAMA GURUKULA
}

\author{
Oleh \\ Ketut Nurhayanti dan Putu Adi Suprapto \\ Jurusan Akuntansi Politeknik Negeri Bali \\ nurhayantiketut@gmail.com
}

Diterima 21 Juni 2018, direvisi 3 Juli 2018, diterbitkan 31 Agustus 2018

\begin{abstract}
This study is to analyze the teachings of yajna as the basis for the character formation of learners in Gurukula Junior High School. As a school that implements the pasraman education system, the Gurukula Junior High School in making the program of activities that will be applied in schools is always based on religious teachings. This research use qualitative research method by using research instrument of interview, observation and also documentation study. The results of data analysis in this study using qualitative description. The result of this study is that the yajna teachings applied in the First Middle School Gurukula is a simple yajna teaching such as cleaning the pasraman environment, cooking for all residents of the dorm, greeting every visitor. The activity is very effective to form and develop the good character of learners like honest, responsible, independent, friendly and polite, discipline and so forth.
\end{abstract}

\section{Keywords: Yajna, Character Character}

\section{PENDAHULUAN}

Pemahaman akan ajaran agama pada jaman modern sangat diperlukan oleh generasi muda bangsa Indonesia. Perubahan gaya hidup yang diakibatkan oleh arus globalisasi seperti sikap yang apatis, hedonisme, degradasi moral, perilaku menyimpang remaja merupakan akibat negatif dari arus globalisasi. Kecenderungan tujuan pendidikan yang hanya menekankan kemampuan intelektual saja menjadikan peserta didik tidak memiliki kemampuan spiritual dan juga emosional yang bisa mengimbangi kemampuan intelektualnya. Permasalahan dalam dunia pendidikan menjadi tanggung jawab semua ele men masyarakat, khususnya sekolah sebagai institusi pendidikan.

Kesuma dkk dalam bukunya yang berjudul pendidikan karakter kajian teori dan praktik di sekolah menyatakan bahwa pendidikan karakter adalah pembelajaran yang mengarah pada penguatan dan pengembangan perilaku anak secara utuh yang didasarkan pada suatu nilai tertentu yang dirujuk oleh sekolah. senada dengan 
pernyataan di atas maka Dony (2004:104) Pendidikan karakter merupakan dinamika pengembangan kemampuan yang berkesinambungan dalam diri manusia untuk mengadakan internalisasi nilai-nilai sehingga menghasilkan disposisi aktif, stabil dalam diri individu. Dinamika ini membuat pertumbuhan individu semakin utuh. Jadi pada dasarnya pembentukan dan pengembangan karakter setiap individu memerlukan suatu tindakan penguatan yang berkesinambungan.

Pendidikan Nasional berfungsi mengembangkan kemampuan dan membentuk karakter serta beradaban bangsa yang bermartabat dalam rangka mencerdaskan kehidupan bangsa. Pendidikan Nasional bertujuan untuk mengembangkan potensi peserta didik agar menjadi manusia yang beriman, berakhlak mulia, sehat, berilmu, cakap, kreatif, mandiri, dan menjadi warga Negara yang demokratis serta bertanggungjawab hal ini sesuai dengan Undang-Undang RI Nomor 20 Tahun 2003 tentang Sistem Pendidikan Nasional. Dari beberapa defenisi tentang pendidikan karakter maka dalam penelitian ini dapat didefensikan sebagai suatu usaha dalam sebuah proses pembelajaran untuk membentuk perilakuperilaku yang baik peserta didik agar mampu untuk menjadi individu yang mandiri dan berguna positif bagi Bangsa.

Sekolah Menengah Pertama Gurukula adalah salah satu lembaga pendidikan formal yang bernunasa agama Hindu dengan menganut sistem pendidikan pasraman yaitu sistem pendidikan yang mewajibkan siswanya untuk tinggal di asrama dengan mengikuti dan mematuhi berbagai peraturan didalamnya. Sekolah yang berbeda dengan sekolah umum ini menggunakan dua kurikulum sebagai dasar dari pelaksanaan proses pembelajarannya yaitu, kurikulum 2013 untuk diterapkan di pendidikan formal dan kurikulum pasraman untuk diterapkan di pasraman. Penerapan kurikulum pasraman lebih banyak menginternalisasi ajaran-ajaran yajna sebagai dasar dari rancangan kegiatan yang akan dilaksanakan.

Pengertian istilah Yajna dalam penelitian ini adalah tidak hanya sebatas pada ritual dan penggunakan berbagai sarana upakara (banten) akan tetapi pengertian yajna sangat luas yaitu membentuk karakter setiap individu (manusia) seperti rasa bhakti, disiplin, mandiri, jujur, bertanggung jawab dan perilaku positif lainnya agar individu tersebut berguna bagi Bangsa dan Negara. Pelaksanaan yajna yang bersifat nitya (seharihari) maupun naimitika (waktu tertentu) menjadi dasar dalam pembentukan karakter peserta didik. Kondisi moral generasi muda yang rusak, ditandai dengan maraknya seks bebas dikalangan remaja, peredaran narkoba dikalangan remaja, tawuran antar pelajar, peredaran video/foto yang mengandung unsur pornografi yang melibatkan remaja memerlukan perhatian khusus dari dunia pendidikan dalam memberikan solusi untuk meminimalisir perilaku yang mengarah kepada hal yang negatif (Kesuma dkk, 2013). Penelitian ini akan menganalisis ajaran yajna yang akan digunakan di Sekolah Menengah Pertama Gurukula Bangli sebagai dasar pembentukan karakter dari peserta didik.

\section{METODE}

Penelitian ini mempergunakan jenis penelitian kualitatif. Sugiyono (2010 : 15) mengatakan bahwa penelitian kualitatif adalah metode penelitian yang berlandaskan pada filsafat postpositivisme, digunakan untuk meneliti pada kondisi obyek yang alamiah, (sebagai lawannya adalah eksperimen) peneliti sebagai instrument kunci, pengambilan sampel sumber data dilakukan secara purposive dan snowball, analisis data menggunakan teknik deskriptif kualitatif yaitu dengan mendiskripsikan hasil analis data secara naratif., dan hasil penelitian kualitatif lebih menekankan makna dari pada generalisasi. jenis pendekatan penelitian yang digunakan dalam penelitian adalah penelitian deskriptif kualitatif. Moleong (2012 : 7) secara tegas menyatakan bahwa pendekatan kualitatif tidak menggunakan desain penelitian yang disusun secara ketat dan kaku, sehingga tidak dapat diubah lagi, melainkan bersifat fleksibel. Dengan demikian desain dalam penelitian ini bersifat sementara dan akan diadakan perubahan-perubahan sesuai dengan kenyataan yang ada di lapangan. 
III. HASIL DAN PEMBAHASAN

\section{A. Analisis Ajaran Yajna Pada Proses Pembelajaran}

Belajar merupakan suatu kegiatan yang mengubah keadaan seseorang menjadi lebih baik : pintar, menjadi orang besar, dan kondisi-kondisi positif lainnya ( Kosasih, 2014:1). Menurut Gagne (dalam Dimyati, 2009:10) belajar merupakan kegiatan yang kompleks, hasil belajar berupa kapabilitas, setelah belajar orang memiliki keterampilan, pengetahuan, sikap dan nilai. Timbulnya kapabilitas tersebut dikarenakan simulasi yang berasal dari lingkungannya dan proses kognitif yang dilakukan oleh pebelajar.

Pembelajaran adalah sebuah proses bagi setiap manusia untuk terus belajar sepanjang hidupnya agar bermanfaat bagi diri sendiri dan orang lain. Hal ini sesuai dengan pernyataan Miarso (2004:528) pembelajaran disebut juga kegiatan pembelajaran instruksional yaitu suatu usaha mengelola lingkungan dengan sengaja agar seseorang membentuk diri secara positif dalam kondisi tertentu. Pada dasarnya kegiatan pembeljaran dirancang bertujuan untuk merangsang interkasi antar peserta didik, peserta didik dengan guru, peserta didik dengan sumber belajar baik berupa buku maupun langsung dari lingkungan sekitarnya yang dapat memberikan pengalaman belajar peserta didik dengan melibatkan proses mental dan juga fisik mereka. Inti sari dari setiap proses pembelajaran yang dilaksanakan adalah membudayakan kebiasaan sehingga menjadi terbiasa. Keterbiasaan peserta didik untuk melaksanakan aktifitas belajar akan membentuk budaya belajar dalam diri setiap peserta didik sehingga terbentuk output yang gemar belajar." Kecanduan" peserta didik untuk belajar tentu saja akan berpengaruh terhadap perilaku keseharian mereka yang cenderung akan membentuk karakter baik

Yajna sebagai salah satu ajaran agama Hindu memiliki kontribusi terhadap pembentukan karakter dari peserta didik. Jika selama ini konsep yajna lebih menekankan kepada ritual keagamaan, maka dalam membentuk karakter peserta didik konsep yajna harus lebih diperluas lagi dengan mengarah pada sebuah konteks pelayanan.
Wujud pelayanan tersebut seperti pelayanan manusia kepada diri sendiri, sesama makhluk hidup dan juga kepada Sang Pencipta.

Suhardana ( 2006 : 102) Selain Yajna dilaksanakan atas dasar untuk menetralisir sifat-sifat manusia, maka yajna juga dilaksanakan dilihat dari segi bentuknya. Apabila ditinjau dari segi bentuknya yajna dapat dibagi menjadi dua, yaitu Yajna yang riil(nyata) atau bersifat skala, misalnya membuat upakara(sesajen dan banten), memberi bantuan kepada yang memerlukan dan lain-lain dan Yajna yang abstrak atau bersifat niskala, misalnya dengan melakukan samadi, yoga, tapa brata, upawasa. Dan berdasarkan pada waktu pelaksanaannya yajna terbagi menjadi dua yaitu nitya yajna yaitu yajna yang dilaksanakan setiap hari dan naimitika yajna yaitu yajna yang dilaksanakan pada waktu tertentu. Yang berkembang pada masyarakat sampai saat ini adalah kecendrungan untuk melaksanakan yajna yang naimitika, hanya pada waktu tertentu seperti sembahyang pada saat hari raya keagamaan saja, membuat sarana upacara keagamaan, dan lain sebagainya. Kecenderunga hanya melaksanakan yajna yang naimitika maka yajna yang nitya dianggap tidak terlalu memiliki peranan yang penting dalam membentuk kebiasaan baik dari setiap individu. Hal ini disebabkan kurangnya pemahaman beberapa masyarakat akan bentuk atau wujud dari pelaksanaan nitya yajna itu sendiri. Oleh karena itu sebagai lembaga pendidikan Sekolah Menengah Pertama Gurukula mencoba menginternalisasi yajna baik dalam bentuk yang nitya maupun naimitika dalam setiap proses pembelajaran baik yang dilaksanakan di dalam kelas (pendidikan formal) maupun di luar kelas (pendidikan non formal) sebagai dasar untuk membentuk karakter peserta didik.

Berikut ini hasil analisis mengenai konsep yajna nitya maupun naimitika yang diterapkan di Sekolah Menengah Pertama Gurukula :

1. Yajna nitya dalam bentuk pelayanan kepada diri sendiri merupakan dalam bentuk kegiatan memenuhi kebutuhan pribadi secara mandiri seperti mencuci 
pakaian sendiri, menyiapkan air dengan mengambil air di sumber air yang dekat dari asrama, membereskan tempat tidur, berpakaian rapi pada saat mengikuti proses pembelajaran formal.

2. Yajna nitya dalam bentuk pelayanan kepada sesama dan lingkungan sekitar dalam bentuk ramah kepada tamu yang berkunjung ke ashram (salam dan sapa), kegiatan penerapan piket memasak untuk seluruh penghuni ashrama, memenuhi kebutuhan air di ashram (mengambil air dari sumber air terdekat kurang lebih jaraknya 200 meter dari ashram), pembersihan gedung ashram, pembersihan lingkungan dalam dan luar ashram, menanam tanamaman baik sayuran maupun obat-obatan tradisioanl di dalam lingkungan ashram, membersihkan kandang ternak sapi dan babi, memberikan makanan pada sapi dan babi, membantu teman belajar pada saat malam hari,

3. Yajna nitya dalam bentuk pelayanan kepada Tuhan dalam bentuk kegiatan kewajiban sembahyang pagi hari (sebelum masuk kelas), siang hari dan sore hari setelah makan malam).

4. Yajna naimitika dalam bentuk kegiatan membuat sendiri sarana upakara yang dibutuhkan pada saat Hari Raya Keagamaan (purnama, tilem, kajeng kliwon, galungan, kuningan, saraswati, pagerwesi, dan lain sebagainya), berperan aktif dalam kegiatan keagamaan di luar lingkungan sekolah.

Penerapan yajna dalam berbagai bentuk kegiatan di atas merupakan pengejawantahan dari Visi Pasraman yaitu VASUDHAIVA KUTUMBAKAM" yang artinya adalah Dunia adalah Sebuah Keluarga. Hal ini sesuai dengan konsep yajna yang lebih luas dalam agama Hindu yang tertuang dalam filosofi "MANAVA SEVA DEVA SEVA" artinya adalah melayani manusia sama dengan melayani Tuhan. Jadi berdasarkan pada analisis konsep ajaran yajna baik yang nitya maupun naimitika dalam model pembelajaran ashram dapat disimpulkan bahwa yajna yang paling sederhana dalam bentuk pembiasaan perilaku untuk mencuci pakaian sendiri, memasak untuk keperluan penghuni asrhama, pembersihan mulai dari kandang ternak sampai kepada gedung yang ada di asrham merupakan cikal bakal dari perkembangan peserta didik menuju hal yang positif.

\section{B. PEMBENTUKAN KARAKTER PESERTA DIDIK}

$\begin{array}{lcr}\begin{array}{c}\text { Sekolah } \\ \text { merencanakan }\end{array} & \text { pang lebih } & \begin{array}{r}\text { banyak } \\ \text { kegiatan }\end{array} \\ \text { pembelajaran } & \text { yang outputnya dapat }\end{array}$
memberikan pengalaman langsung kepada peserta didik dapat lebih cenderung mampu untuk membentuk karakter peserta didik dibandingkan dengan proses pembelajaran yang bersifat mentransfer ilmu pengetahuan secara teoritis di kelas kepada peserta didik. Hal ini sesuai dengan hasil penelitian dari Marleny dan John terkait dengan Sekolah yang menerapkan program full day school, yaitu satu program untuk menambah jam sekolah sehingga peserta didik akan berada di lingkungan sekolah dari pagi sampai sore hari. Penambahan jam belajar lebih banyak di isi dengan kegiatan ekstrakurikuler sehingga peserta didik tidak mengalami kebosanan di sekolah. kegiatan ekstrakurikuler tersebut lebih menerapkan kepada proses pembiasaan sikap baik seperti disiplin,. jujur, mandiri dan lain sebagainya. Jadi proses pembelajaran yang dilaksanakan di sekolah dengan menerapkan program full day school dengan membiasakan peserta didik secara terus menerus melakukan tindakan moral. Program ini memiliki repson yang positif, bermanfaat untuk menanamkan nilai-nilai kebaikan kepada peserta didik.

Hasil peneltian Suhardi mengenai sekolah berbasis pesantren cukup mampu untuk membentuk karakter peserta didik dengan mengkolaborasikan sistem pendidikan formal dan non formal (sistem pendidikan pesantren). Sistem pendidikan ini tidak hanya mampu untuk membentuk peserta didik memiliki kecerdasan intelektual melainkan juga kecerdasan emosional dan juga spiritual. Walaupun pada dasarnya ada berbagai kekurangan dalam 
mengimplementasikannya setiap kegiatan yang sudah direncanakan. Hasil penelitian dari Suhardi memperkuat pernyataan bahwa kolaborasi antara sistem pendidikan formal dengan non formal efektif untuk membentuk karakter peserta didik. Sekolah Menengah Pertama Gurukula yang menggunakan sistem pendidikan dengan mengkolaborasikan pendidikan formal dan juga non formal yaitu pendidikan pasraman saat ini berkontribusi terhadap pembentukan dan perkembangan karakter baik dari peserta didik. Dasar dari pembentukan karakter di Sekolah Menengah Pertama Gurukula adalah dengan menginternalisasi ajaran yajna dalam setiap kegiatan.

Pembelajaran di Sekolah Menengah Pertama Gurukula yang membentuk karakter peserta didik terdapat pada proses pembiasaan melalui kegiatan-kegiatan yang mengarah pada proses pembentukan sikap religius, dispilin, mandiri, tangguh, jujur, ramah, sopan, empati, perduli lingkungan, bersih, dan karakter baik lainnya. Seperti pembiasaan untuk membentuk karakter mandiri dan tangguh kepada peserta didik dengan mewajibkan setiap peserta didik untuk memenuhi kebutuhan air untuk keperluan pribadi dengan mengambil air dari sumber mata air yang jaraknya 100 meter dari asrama. Karakter dispilin dibentuk melalui kegiatan mentaati seluruh peraturan yang ada di asrama jika ada yang melanggar maka ada sanksi ringan seperti pemberian nasehat, sampai dengan pemberhentian menjadi siswa di Sekolah Menengah Pertama Gurukula. Karakter bersih dan perduli lingkungan melalui proses kegiatan piket seperti membersihkan seluruh gedung di lingkungan sekolah dan asrama, membersihan kandang peternakan, membersihkan lingkungan sekitar sekolah dan asrama, membuang sampah pada tempatnya, kegiatan tersebut dibuat sebagai bagian dari peraturan asrama, sehingga jika ada salah satu peserta didik yang tidak mau melaksanakan kegiatan tersebut maka akan terus dilaksanakan pembinaan jika tetap tidak bisa melaksanakan kegiatan tersebut maka konsekuensinya adalah dikeluarkan dari sekolah. Pembiasaan yang dibentuk berdasarkan pada kegiatan rutin yang dilaksanakan di sekolah memerlukan pengawasan, evaluasi secara berkelanjutan, dan dalam hal ini komitemen untuk terus melaksanakan proses pengawasan dan evaluasi sangat penting agar tujuan terbentuknya karakter baik pada peserta didik akan tercapai.

Mulyasa (2011 : 14) untuk menyukseskan pendidikan karakter di sekolah adalah dengan memahami hakikat pendidikan karakter dengan baik. Hal ini sangat penting karena pendidikan karakter bergerak dari kesadaran, pemahaman, kepedulian, komitmen, menuju suatu tindakan. Selanjutnya Driyarkarya menjelaskan bahwa individu pada dasarnya memiliki karakter yang baik dan tidak baik. Tugas dari pendidikan adalah mengembangkan karakter baik dan membantu mengurangi karakter tidak baik. Driyarkarya menekankan bahwa sebagai pribadi manusia tidak boleh hanya mengikuti bakat bawaan tetapi harus berani mengembangkan dan mengubah yang tidak baik. (Driyakarya (2006 :488-494).

Kondisi moralitas bangsa Indonesia pada khususnya dan dunia pada umumnya menuntut adanya perubahan tujuan pendidikan yang tidak lagi menekankan pada kecerdasan intelektual siswa, melainkan pada pengembangan karakter. Terlebih paradigma pendidikan abad 21 yang menekankan pada perubahan perilaku individu sebelum dan sesudah menempuh pendidikan. Perkembangan dunia tidak hanya dalam bidang ilmu pengetahuan dan teknologi melainkan juga perkembangan paradigm mengenai generasi era sekarang yang memiliki perbedaan dengan generasi pada jaman dahulu. Generasi era sekarang disebut dengan generasi digital yang lebih berinteraksi dengan teknologi dibandingkan dengan lingkungan sekitar.

Pendidikan karakter dapat di mulai dari keluarga, sekolah dan masyarakat. Sekß̄lah Menengah Pertama Gurukula yang menerapkan sistem pendidikan pasraman memiliki tanggung jawab lebih besar dibandingkan dengan sekolah umum lainnya terhadap pengembangan karakter siswa, karena siswa tinggal di sekolah (asrama), sehingga tidak ada peranan keluarga dalam 
mengembangkan karakter siswa selama masa pendidikan. Proses pembentukan karakter siswa di Sekolah Menengah Pertama Gurukula melalui kegiatan- kegiatan yang dilaksanakan di sekolah baik pada saat proses pembelajaran formal maupun pasraman. Berikut ini merupakan tabel contih kegiatan untuk membentuk karakter peserta didik di Sekolah Menengah Pertama Gurukula.

Tabel 5.4.1 Contoh Kegiatan Untuk Membentuk Karakter Peserta Didik Di Sekolah Menengah Pertama Gurukula

\begin{tabular}{|c|c|c|}
\hline No & Kegiatan & Karakter \\
\hline 1 & Memberi salam "Om Swastyastu” & Ramah, sopan \\
\hline 2 & $\begin{array}{l}\text { Melaksanakan upacara bendera setiap hari senin } \\
\text { atau hari nasional }\end{array}$ & Nasionalisme, disiplin \\
\hline 3 & $\begin{array}{l}\text { Melaksanakan sembahyang setiap pagi, siang dan } \\
\text { sore hari }\end{array}$ & Religius \\
\hline 4 & Berdoa sebelum memulai pembelajaran di kelas & Religius \\
\hline 5 & Membuang sampah pada tempatnya & Tanggung jawab, jujur \\
\hline 6 & $\begin{array}{l}\text { Membersihkan lingkungan sekitar sekolah } \\
\text { (gedung dan di luar gedung) secara rutin }\end{array}$ & Tanggung jawab, tangguh \\
\hline 7 & $\begin{array}{l}\text { Melaksanakan piket memasak untuk keperluan } \\
\text { seluruh penghuni ashrama (mulai dari } \\
\text { menyediakan bahan makanan sampai pada tahap } \\
\text { mengolah bahan makanan tersebut) }\end{array}$ & $\begin{array}{l}\text { Tanggungjawab, tangguh, } \\
\text { mandiri. }\end{array}$ \\
\hline 8 & $\begin{array}{l}\text { Membantu adik kelas atau teman sekelas belajar } \\
\text { malam }\end{array}$ & Tolong menolong \\
\hline 9 & Menyiapkan keperluan air untuk mandi & Mandiri, tangguh \\
\hline 10 & $\begin{array}{l}\text { Membersihkan kandang ternak sapi dan babi } \\
\text { setiap hari }\end{array}$ & Tanggung jawab, tangguh \\
\hline 11 & Menyiapkan sarana ritual keagamaan di sekolah & $\begin{array}{l}\text { Religius, mandiri, tanggung } \\
\text { jawab }\end{array}$ \\
\hline
\end{tabular}

Proses pembentukan karakter di Sekolah Menengah Pertama Gurukula dilaksanakan dengan kegiatan yang mengarah kepada moral being yaitu membiasakan peserta didik untuk melaksanakan perilaku moral secara terus menerus, bukan hanya sekedar mengetahui informasi terkait dengan perilaku baik dan perilaku buruk. Sebagian besar kegiatan tersebut lebih banyak di terapkan pada saat siswa tidak dalam kondisi di dalam kelas tapi lebih banyak di luar kelas pada saat jam pelajaran secara formal telah selesai.

\section{KESIMPULAN}

Berdasarkan pada hasil penelitian maka dapat disimpulkan bahwa Sekolah Menengah Pertama Gurukula sebagai sekolah yang berbasis agama dengan menerapkan ajaran agama seperti yajna dalam setiap kegiatan yang direncanakan baik itu untuk pembelajaran di kelas maupun di luar kelas sangat efektif untuk membentuk dan mengembangkan karakter baik peserta didik. Hasil analisis ajaran yajna yang diterapkan dalam proses pembelajaran baik di dalam kelas maupun diluar kelas sangatlah sederhana mulai dari membiasakan peserta didik untuk berdoa sebelum memulai pelajaran, berpakaian rapi, memungut dan membuang sampah pada tempatnya, membersihkan lingkungan sekolah semua kegiatan tersebut tergolong dalam bentuk yajna yang membentuk karakter baik peserta didik. Kegiatan tersebut dilaksanakan dengan pengawasan dan evaluasi dari pihak sekolah secara berkelanjutan, karena pada dasarnya pembentukan dan pengembangan karakter baik setiap individu memerlukan komitmen dari individu itu sendiri serta pengawasan dari pihak lain. 
DAFTAR PUSTAKA

Dimyati dan Mudjionon. (2009). Belajar dan Pembelajaran. Jakarta : Rineka Cipta

Dony, K. (2004). Pendidikan Karakter. Jakarta: Grasindo

Driyakarya. (2006). Karya Lengkap Driyarkara. Penyunting: A. Sudiarja, G. Budi Subanar, St. Sunardi, dan T Sarkim. Jakarta : PT Gramedia Pustaka Utama

Kesuma, D. dkk. (2013). Pendidikan Karakter Kajian Teori dan Praktik di Sekolah. PT Remaja Rosdakarya. Bandung.

Kosasih. (2016). Strategi Pembelajaran Implementasi Kurikulum 2013. Bandung : Yrama Widya

Leasa, M., \& Batlolona, J. R. (2017). Full Day School dalam Pembentukan Karakter Siswa SMKN 13 Kota Malang. Jurnal Ilmu Sosial dan Humaniora, 6(1), 73-82.

Miarso, Y. (2004). Menyemai Benih Teknologi Pendidikan. Jakarta : Prenada Media
Moleong, L. (2012). Metodologi Penelitian Kualitatif. Bandung : Remaja Rosdakarya

Mulyasa. (2011). Manajemen Pendidikan Karakter. Jakarta: Bumi Aksara.

Payuyasa, I. N. (2017). TUMPEK UDUH, KEARIFAN LOKAL BALI UNTUK MENINGKATKAN MUTU PENDIDIKAN KARAKTER. Jurnal Penjaminan Mutu, 3(2), 206-214.

Suhardi, D. (2012). Peran SMP Berbasis Pesantren Sebagai Upaya Penanaman Pendidikan Karakter Kepada Generasi Bangsa. Jurnal Pendidikan Karakter, (3). Sugiyono (2010). Metode Penelitian Pendidikan Pendekatan Kuantitif, Kualitatif dan R \& D. Alfabeta. Bandung Suhardana, K. M. (2006). Memaknai Kesejagatan Agama Hindu. Panakom. Denpasar 